\title{
Migration, public health and human rights
}

\author{
Michael Knipper
}

Received: 19 August 2016/Accepted: 1 September 2016/Published online: 18 October 2016

(c) Swiss School of Public Health (SSPH+) 2016

What is the meaning of the "human right to health" in the light of the European refugee reception crisis? The avoidable harm, suffering and dying of refugees inside Europe and at the European Union's external borders are mortifying. Considering the obvious 'disgrace' (Razum and Bozorgmehr 2015) in Mediterranean seas, at the razor wire border fences on the Balkans, at the Spanish enclaves of Melilla and Ceuta, or in places like the notorious camp at Calais, it may be difficult to believe that human rights have any real power to protect, or still less, to improve health and well-being of the people fleeing in desperation from war and terror. If even the wealthy democracies of the geopolitical West, usually so proud of their commitment to human rights and the rule of law, fail to comply with basic international legal commitments: what can be expected of human rights, and the rights-based approach to health, at all?

Despite all doubts, the answer is clear: very much can be expected of human rights including the right to health, but only under the condition that all stakeholders-including civil society, universities, academics, and citizens at large - take a stand and engage. The reluctance of states to seriously apply human rights "at home" is actually not a surprise: human rights oblige governments to attend to the particular needs of the marginalized, the weak, and the powerless. It was precisely the historical awareness of the vulnerability of minorities that motivated the authors of the Universal Declaration of Human Rights (UDHR) in the late 1940s. In the drafting process, one of the most controversial points was just the question whether state sovereignty

M. Knipper ( $\square)$

Institute of the History of Medicine, University Justus Liebig, Giessen, Germany

e-mail: Michael.Knipper@histor.med.uni-giessen.de should be limited by unconditioned individual rights and supra-national institutions like the UN (Glendon 2001). The observed disregard of human rights by states does not undermine but reaffirms the relevance of human rights and the need of governments for external control and other kinds of "support" - by political institutions like the UN, but also by civil society including science.

What does this mean for Public Health? "Support" for governments and commitment to human rights entails two dimensions: punishment and prevention (cf. Glendon 2001: xvi). "Punishment" consists in the legal and political procedures to hold states accountable to internationally agreed human rights standards and norms, primarily through human rights treaty-monitoring bodies on UN or regional (e.g. European) levels (cf. Toebes 2015). A further possibility is to take human rights issues to court. In this context, knowledge and evidence from public health research, e.g. on the detrimental health effects of detention and other legal procedures on refugees (Silove et al. 2007; Lamkaddem et al. 2015; Chauvin et al. 2015), can be crucial. Research evidence is also needed for advocacy, bearing in mind that governments are not monolithic but made up of individual people who can be convinced by meaningful data.

Much closer to public health is, however, the second dimension: "prevention". The right to health is actually a perfect illustration of the preventive dimension of a comprehensive understanding of all human rights, as interdependent and indivisible (cf. Mann et al. 1996): as a foundation of freedom, justice and peace, as prevention of discrimination, oppression, avoidable suffering and harm. According to the basic legal documents, the right to health is 'indispensable for the exercise of other human rights' (e.g. political rights) and supported by numerous human right instruments (UN CESCR 2000). Its meaning 
explicitly transcends access to health care. States are obliged to 'respect, protect and fulfil' the 'highest attainable standard of health' (UN CESCR 2000) based on the assumption that health depends on determinants beyond the control of the individual (e.g. social, economic, political) (Toebes 2015). The history of AIDS, for example, offers clear evidence of the detrimental effect of human rights violations (e.g. social stigma and exclusion) on health, and has also shown that "public health efforts that consider human rights are more likely to be effective than those that neglect or violate rights' (Gruskin et al. 2007: 453). Human rights-based approaches to health include promotion of human rights principles like non-discrimination, participation and empowerment, explicit attention to the particular needs of vulnerable groups (Silberhorn 2015), and systematic assessment of the 'availability, accessibility, acceptability and quality' of health services (UN CESCR 2000). Measured against these standards, the current approach to migrants' health, e.g. in Germany is insufficient (Brzoska et al. 2015; Razum and Bozorgmehr 2016).

The highest attainable standard of physical and mental health is an important condition for 'living a life in dignity' (UN CESCR 2000). In the case of refugees and migrants, it is indispensable for a full and successful integration into a new society. Putting this claim into practice is not an easy task. The public health community has an essential role to play in this endeavor.

Acknowledgments The author would like to thank David Ingleby and Sarah Willen for inspiring conversations on the argument and earlier drafts of this paper.

\section{References}

Brzoska P, Ellert U, Kimil A, Razum O, Sass A-C, Salman R, Zeeb H (2015) Reviewing the topic of migration and health as a new national health target for Germany. Int $\mathrm{J}$ Public Health 60(1):13-20. doi:10.1007/s00038-014-0617-z

Chauvin P, Simonnot N, Vanbiervliet F, Vicart M, Vuillermoz C (2015) Access to healthcare for people facing multiple vulnerabilities in health in 26 cities across 11 countries. Report on the social and medical data gathered in 2014 in nine European countries, Turkey and Canada. Doctors of the World-Médecins du monde international network, Paris

Glendon MA (2001) A world made new: Eleanor Roosevelt and the Universal Declaration of Human Rights, 1st edn. Random House, New York

Gruskin S, Mills EJ, Tarantola D (2007) History, principles, and practice of health and human rights. Lancet 370(9585):449-455. doi:10.1016/S0140-6736(07)61200-8

Lamkaddem M, Essink-Bot ML, Devillé W, Gerritsen A, Stronks K (2015) Health changes of refugees from Afghanistan, Iran and Somalia: the role of residence status and experienced living difficulties in the resettlement process. Eur J Public Health 25(6):917-922

Mann JM, Gostin L, Gruskin S, Brennan Tm Lazzarini Z, Fineberg HV (1996) Health and human rights. Health Hum Rights $1(1): 6-23$

Razum O, Bozorgmehr K (2015) Disgrace at EU's external borders. Int J Public Health 60(5):515-516. doi:10.1007/s00038-0150689-4

Razum O, Bozorgmehr K (2016) Restricted entitlements and access to health care for refugees and immigrants: the example of Germany. Global Soc Policy. doi:10.1177/1468018116655267

Silberhorn T (2015) Germany's experience in supporting and implementing human rights-based approaches to health, plus challenges and successes in demonstrating impact on health outcomes. Health Hum Rights 17(2):21-29

Silove D, Austin P, Steel Z (2007) No refuge from terror: the impact of detention on the mental health of trauma-affected refugees seeking asylum in Australia. Transcult Psychiatry 44(3):359-393

Toebes B (2015) Health and human rights: in search of the legal dimension. Hum Rights Int Legal Discourse 9(2):212-241

UN CESCR (2000) Substantive issues arising in the implementation of the International Covenant on Economic, Social and Cultural Rights: General Comment No. 14 (2000). The right to the highest attainable standard of health (article 12 of the International Covenant on Economic, Social and Cultural Rights) 